Article

\title{
Assessment of Importance and Characteristics of Biophilic Design Patterns in a Children's Library
}

\author{
Hyo Chang Lee ${ }^{1}$ and Sung Jun Park ${ }^{2, *}$ \\ 1 Department of Interior Architecture \& Built Environment, Yonsei University, Seoul 120-749, Korea; \\ spdlee@naver.com \\ 2 Department of Architectural Engineering, Keimyung University, Daegu 42601, Korea \\ * Correspondence: sjpark@kmu.ac.kr; Tel.: +82-53-580-5765
}

Received: 17 January 2018; Accepted: 23 March 2018; Published: 27 March 2018

\begin{abstract}
This paper stresses the results of a consciousness survey on the characteristics of biophilic design elements and patterns applied within a children's library. Biophilic design is a sustainable design strategy that intends to bring about positive change in users by integrating and linking people and nature. The aim of this study is to suggest a space design method for children's libraries, applying several natural elements based on biophilic design patterns. To investigate space design characteristics based on the biophilic design of children's libraries, we summarized the elements that have been included in patterns of biophilic design in previous studies, and analyzed the characteristics of biophilic design patterns in children's libraries through case studies. Also, we conducted a questionnaire survey from 261 caregivers of children's libraries. The conclusions are as follows. First, children's libraries need to offer an experience of nature, considering a natural ecosystem. Second, children's libraries need natural shelter space designs and open space designs based on natural elements. Third, children's libraries need multi-functional space designs that enable reading, rest, gathering, play, performance, and facilitate children of various ages interacting with each other. Fourth, children's libraries need space designs that can induce interest and experiences by various forms of sensory information created by natural elements. This research intends to find out the priority application method of biophilic design patterns and elements of a children's library through a survey of caregivers' consciousness, and contribute greatly to the potential possibilities of the application of biophilic designs to indoor spaces.
\end{abstract}

Keywords: biophilic design; children's library; space design; children; library

\section{Introduction}

Recently, local governments in Korea have been developing and implementing various programs for children's education, culture, and exchange, as well as establishing and expanding children's libraries. The creation of diverse community environments for children is a very desirable phenomenon. The development of children's library projects can promote cognitive and emotional development during the key period of a child's growth process as a human being, through education, reading, and social exchange. They are also very beneficial for social and cultural development [1].

An environment for children should consider the physical and mental characteristics of children, as well as the support provided in consideration of the children's growth and exchange between children. Children interact with the environment, and their daily activities and experiences greatly influence their growth and development. Therefore, the children's library is a facility that needs active support for and careful consideration of the physical, emotional, and social development of children, in addition to support for learning. Nature is one of the most important factors that help children's 
overall growth and development; it is well known that nature has a positive impact on children in various ways [2,3].

However, research on the systematic application of natural elements in children's libraries is still insufficient [4]. In this paper, we try to find a solution to this problem by exploring the applications of biophilic design, which is a social sustainability that intends to bring about positive change in users by integrating and linking people and nature. The aim of this study is to suggest a space design method for children's libraries, applying several natural elements based on 'biophilic design' patterns.

\section{Research Method and Scope}

To investigate space design characteristics based on the biophilic design of children's libraries, we first established the necessity of children's libraries and the concept of biophilic design, and summarized the elements that have been included in patterns of biophilic design in previous studies. Second, we analyzed the characteristics of biophilic design patterns in children's libraries through case studies. Third, we developed our survey tools through integrating and classifying the similar or duplicate items of biophilic design patterns in children's libraries. The Likert five-point scale was used as the survey items. In order to enhance the understanding of survey respondents, we summarized survey items, and also provided photographs of case studies. Fourth, we conducted a questionnaire survey from 6 January 2017 to 29 January 2017, which included 261 parents who were visitors of children's libraries. Finally, we collected and analyzed the data by frequency, average, and factor analysis using SPSS.

\section{Literature Review}

\subsection{The Necessity of Applying Natural Elements in Children's Libraries}

Bronfenbrenner advocated for physical, emotional, and social development theories in children's ecological aspects, and argued that children's growth and development are influenced by everyday experiences within the environmental system surrounding them [5]. Environmental systems interact directly with children, and are most influenced by the microsystem in which children are engaged in many activities. The microsystem includes a variety of facilities, such as home environments, child care facilities, schools, and children's libraries, which show that the physical, emotional, and social development stages of children are directly affected by their surrounding environment [6]. The children's library is a space to collect, organize, and archive data related to children growth and education, and bring out ideas, imaginations, and creative expressions through listening, reading, speaking, communicating, touching, and thinking in the children's library [7]. Children's libraries are significant resources that can fuel imagination and creative expression, as well as build data for and serve children. In addition, the children's library is a kind of public social place for children, a recreational facility, and they also have significance as a place for self-education [8]. In other words, the children's library environment should play a role in actively supporting the growth and development of children, beyond just providing a place for approaching and reading various books [9].

The nature-friendly environment introduced by the application of various natural elements, such as light, plants, water, soil, and stone, in the main education and play space of children aims at peaceful and cooperative human growth; it contributes positively to the creative and active growth of children. In particular, these natural factors enable the formation of a comfortable living educational space that supports the physical, mental, social, and cognitive development of children [10]. Considering the positive impact of nature on children, the application of natural elements in libraries that children frequently use will create an environment that feeds both the physical and the mental needs of children. 


\subsection{The Concept and Patterns of Biophilic Design}

Nature's positive effects on humans have been asserted through previous theories. Notable related theories are the attention restoration theory, the stress recovery theory, and the biophilia hypothesis.

Attention restoration theory [11] is a representative theory that posits that human have an unlearned predisposition to pay attention and respond positively to natural content (e.g., vegetation, water). In other words, in mental fatigue, which modern people frequently suffer from, one cannot effectively carry out daily activities, so he/she must maintain a certain level of attentiveness to maintain a healthy daily life. The 'restorative environment' for this purpose means an environment that can restore exhausted attention. The natural environment, which is represented by the forest to modern people tired of urban life, is a typical recovery environment that emphasizes the need for this theory.

The stress recovery theory proposed by Ulrich et al. is a representative theory that explains psycho-evolutionary theory. The evolutionary perspective suggests that because humans evolved in the natural environment over a long time period, they are to some extent physiologically and psychologically adapted to natural environments [12]. In other words, in periods of physiological stress, when people experience the environment, the positive emotional reactions of the initial affirmation of the environment reduce the negative excitement and reaction, initiating the stress recovery process. In particular, natural factors, such as vegetation, water systems, natural textures, and landscapes, are sufficient to provide a more intentional recovery experience by generating positive emotions about the environment.

The biophilia hypothesis posits that there is an instinctive relationship between humans and other ecosystems. Biophilia is a compound word comprised of 'bio' (life) and 'philia' (love). This theory implies the human being's inherent attachment to nature [12]. Biophilic design attempts to combine the benefits of nature with human spaces in an active and systematic way. It is a design concept and a standard that aims to make active use of various elements of nature and its changes in architectural environment design. In addition, biophilic design aims to integrate and utilize various natural elements in the architectural environment to satisfy the human instinct to be exposed to nature and utilize it [13]. The biophilic design patterns presented through a previous study [14] are shown in Table 1.

Table 1. Biophilic Design Patterns.

\begin{tabular}{|c|c|c|}
\hline \multicolumn{2}{|c|}{ Biophilic Design Patterns } & Definition \\
\hline \multirow{4}{*}{ Nature in Space } & Visual Connection with Nature & $\begin{array}{l}\text { Provision of internal and external nature, } \\
\text { ecosystem, and its change. }\end{array}$ \\
\hline & Non-Visual Connection with Nature & $\begin{array}{l}\text { Provision of auditory, olfactory, tactile, and } \\
\text { gustatory stimulation of nature, ecosystems, and } \\
\text { their changes. }\end{array}$ \\
\hline & Dynamic \& Diffuse Light & $\begin{array}{l}\text { Provision of a lively environment with nature } \\
\text { through lights and shadows. }\end{array}$ \\
\hline & Connection with Natural Systems & $\begin{array}{l}\text { Provision of an environment where visitors can } \\
\text { feel the changes of a healthy nature, such as the } \\
\text { change of the seasons. }\end{array}$ \\
\hline \multirow{3}{*}{ Production of Nature } & Biomorphic Forms \& Patterns & $\begin{array}{l}\text { Symbolism, such as shapes, patterns, materials, } \\
\text { and ratios that can be observed in nature. }\end{array}$ \\
\hline & Material Connection with Nature & $\begin{array}{l}\text { Minimizing processing, and providing natural } \\
\text { materials that show the ecological characteristics } \\
\text { of the area. }\end{array}$ \\
\hline & Complexity \& Order & $\begin{array}{l}\text { Provision of an environment where visitors can } \\
\text { sense various forms of sensory information from } \\
\text { nature, centered on the hierarchy of natural } \\
\text { elements. }\end{array}$ \\
\hline \multirow{2}{*}{ Characteristics of Space } & Prospect & $\begin{array}{l}\text { Provision of an open environment to observe, } \\
\text { view, and monitor the surrounding environment. }\end{array}$ \\
\hline & Refuge & $\begin{array}{l}\text { Provision of a place where visitors can feel safe } \\
\text { and protected from environmental changes. }\end{array}$ \\
\hline
\end{tabular}


The biophilic design patterns can be divided into 'nature inside space', the 'direction of nature', and 'space characteristics'; they can also be further classified into nine patterns in total. The biophilic design pattern is a more concrete example of the architectural application of the experience and characteristics of biophilic design, as shown in Table 2 [14].

Table 2. The Experience and Characteristices of Biophilic Deisgn.

\begin{tabular}{cc}
\hline Experience & Characteristics \\
\hline A direct experience of nature & Natural light, water, plants, weather, natural scenery, ecosystem \\
Indirect experience of nature & The image of nature, natural materials, the geometry of nature \\
Experience of space and place & View and shelter, attachment to cultural and ecological sites \\
\hline
\end{tabular}

\section{A Case Study of the Biophilic Design of Children's Libraries}

A total of 20 overseas children's libraries were selected for this study, and a case study was carried out in order to understand the characteristics of biophilic design patterns in children's libraries. For this purpose, this study selected the children's reading rooms of children's libraries or public libraries located overseas and built after 2006, as shown in Table 3.

Table 3. Selected Children's Libraries.

\begin{tabular}{cccc}
\hline Children's Library Name & Location & Bldg. Area $\left.\mathbf{( m}^{\mathbf{2}}\right)$ & Year of Construction \\
\hline Anacostia Library & USA & 22,000 & 2011 \\
Bendigo Library & Australia & 4010 & 2014 \\
Bishan Public Library & Singapore & 1400 & 2006 \\
CALS Children Library i & USA & 3576 & 2013 \\
City Library in Seinäjoki & Finland & 4430 & 2012 \\
Columbia Public Library & USA & 2497 & 2009 \\
Cooroy Library & Australia & 1650 & 2010 \\
Fernando Botero Park Library & USA & 23,039 & 2009 \\
Glen Oaks Branch Library & USA & 1672 & 2013 \\
Hercules Public Library & USA & 1873 & 2006 \\
Lawrence Public Library & USA & 2090 & 2014 \\
Los Gatos Public Library & USA & 29,240 & 2012 \\
McAllen Main Library & USA & 11,612 & 2011 \\
New Public Library Zoersel & Belgium & 1421 & 2014 \\
Public Library Amsterdam & Netherlands & 28,500 & 2007 \\
Schertz Public Library & Australia & 1913 & 2009 \\
Surry Hills Library & Australia & 2497 & 2009 \\
Valley-Hi North Laguna Library & USA & 1904 & 2011 \\
Vaughan Civic Centre Resource Library & Canada & 3306 & 2016 \\
Whitehall Library & USA & 1811 & 2015 \\
\hline
\end{tabular}

Selected children's libraries are located in the United States (USA), Canada, Australia, Finland, Belgium, the Netherlands, Singapore, and Colombia. The building area is $1400-29,240 \mathrm{~m}^{2}$, and the construction period is 2006-2016. The results are shown in Table 4. 
Table 4. The Characteristics of Biophilic Design Patterns in Children's Libraries

Biophilic Design Patterns

Nature Inside the Space

ans

Visual Connection with Nature

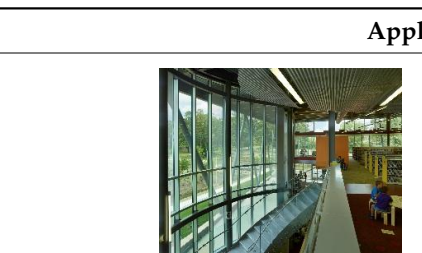

CALS Children Library

Visual connection with nature by such as library shelf/reading space,

and a large-scale open space.

pplications of Characteristics of Biophili

New Public Library Zoersel Visual connection with nature by such as library shelf/reading, space and a large-scale open space.

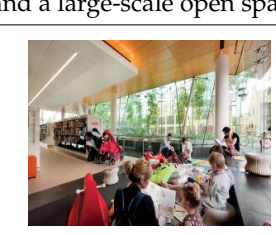

Surry Hills Library

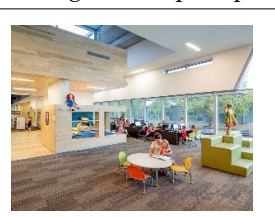

Lawrence Public Library

Space design that facilitates visual connection with nature in a learning

Space design that facilitates visual connection with nature in a learning space with a long stay time.

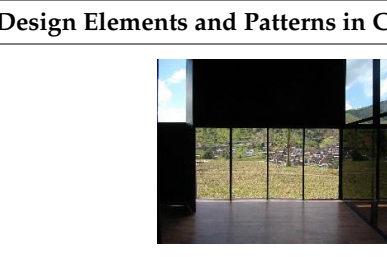

Fernando Botero Park Library Delivering a new image of nature through partial blocking of the external view.

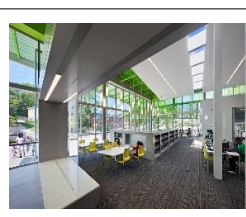

Anacostia Library dren's Libraries

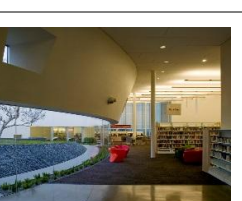

Hercules Public Library Space design that can stably and comfortably allow for gazing at the nature outside, while seated indoors.

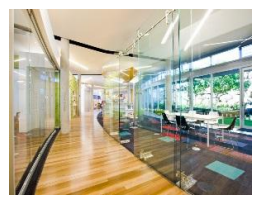

Using the light transmitted through Space design that facilitates visibility of the nature outside in where the nature outside looks greener. penetration of the
overlapping spaces.

\begin{tabular}{ccccc}
\hline $\begin{array}{c}\text { Non-Visual Connection } \\
\text { with Nature }\end{array}$ & $\begin{array}{c}\text { Bendigo Library } \\
\text { The play/learning space that } \\
\text { naldren often touch is enclosed with } \\
\text { natural materials, such as wood, to } \\
\text { provide tactile and } \\
\text { olfactory stimulation. }\end{array}$ & $\begin{array}{c}\text { Natural materials such as wood used } \\
\text { on the space elements with various } \\
\text { functions, such as key height } \\
\text { measurements, to provide tactile and } \\
\text { olfactory stimulation. }\end{array}$ & $\begin{array}{c}\text { Sand playground in the outer space } \\
\text { to provide tactile stimulation by } \\
\text { natural elements. }\end{array}$ & $\begin{array}{c}\text { Provision of natural tactile and } \\
\text { oufactory stimulation through } \\
\text { functions such as gathering, play, } \\
\text { and performance. }\end{array}$ \\
\hline
\end{tabular}


Table 4. Cont

\begin{tabular}{|c|c|c|c|c|c|}
\hline \multicolumn{2}{|c|}{ Biophilic Design Patterns } & \multicolumn{4}{|c|}{ Applications of Characteristics of Biophilic Design Elements and Patterns in Children's Libraries } \\
\hline & \multirow{4}{*}{$\begin{array}{l}\text { Provision of Dynamic } \\
\text { Light in the Environment }\end{array}$} & Bishan Public Library & Bendigo Library & Columbia Public Library & Lawrence Public Library \\
\hline & & $\begin{array}{l}\text { Provision of dynamic light in spaces, } \\
\text { such as intensive learning spaces and } \\
\text { lobbies, by allowing natural light to } \\
\text { pass through the skylight. }\end{array}$ & $\begin{array}{l}\text { Exposing the sky through the ceiling, } \\
\text { providing a natural ecosystem view } \\
\text { and dynamic light in the } \\
\text { environment, on the shelves, and in } \\
\text { the viewing and moving spaces. }\end{array}$ & $\begin{array}{l}\text { Exposing the sky through the } \\
\text { ceiling, providing a natural } \\
\text { ecosystem view and dynamic light } \\
\text { in the environment, on the shelves, } \\
\text { and in the viewing, and } \\
\text { moving spaces. }\end{array}$ & $\begin{array}{l}\text { Exposing the sky through the } \\
\text { ceiling, providing a natural } \\
\text { ecosystem view and dynamic ligh } \\
\text { in the environment, on the shelves } \\
\text { and in the viewing and } \\
\text { moving space. }\end{array}$ \\
\hline & & Whitehall Library & Glen Oaks Branch Library & Cooroy Library & City Library in Seinäjoki \\
\hline & & $\begin{array}{l}\text { Providing natural lighting } \\
\text { dynamically and an environment for } \\
\text { the viewing, playing, and learning } \\
\text { space with a long stay time. }\end{array}$ & $\begin{array}{l}\text { Providing a moving space around the } \\
\text { skylight to allow for natural light to } \\
\text { be transmitted and form interesting } \\
\text { patterns, such as shadows. }\end{array}$ & $\begin{array}{l}\text { Providing a dynamic light in the } \\
\text { environment that changes } \\
\text { momentarily in the shelf, reading, } \\
\text { and moving spaces, by allowing } \\
\text { natural light to pass through } \\
\text { the window. }\end{array}$ & $\begin{array}{l}\text { Providing a dynamic light in the } \\
\text { environment that changes } \\
\text { momentarily in the shelf, reading, } \\
\text { and moving spaces by allowing fo } \\
\text { natural light to pass through } \\
\text { the window. }\end{array}$ \\
\hline \multirow[t]{2}{*}{ Nature in Space } & $\begin{array}{l}\text { Provision of Dynamic } \\
\text { Light in the Environment }\end{array}$ & Valley-Hi North Laguna Library & Public Library Amsterdam & Surry Hills Library & Los Gatos Public Library \\
\hline & & $\begin{array}{l}\text { Natural light passing through the } \\
\text { windows provides a dynamic } \\
\text { lighting environment that changes } \\
\text { instantly in the reading and } \\
\text { moving areas. }\end{array}$ & $\begin{array}{l}\text { Provision of artificial lighting with } \\
\text { specific functions, such as floor } \\
\text { movement guidance and a dynamic } \\
\text { emphasis on vertical movement } \\
\text { space and sunken space. }\end{array}$ & $\begin{array}{l}\text { Provision of artificial lighting with } \\
\text { specific functions, such as floor } \\
\text { movement guidance and a } \\
\text { dynamic emphasis on vertical } \\
\text { movement space and sunken space. }\end{array}$ & $\begin{array}{l}\text { Provision of a dynamic light in the } \\
\text { environment through a finishing } \\
\text { material that provides various } \\
\text { materials for reflectance, such as } \\
\text { transmission, reflection, and color. }\end{array}$ \\
\hline
\end{tabular}


Table 4. Cont

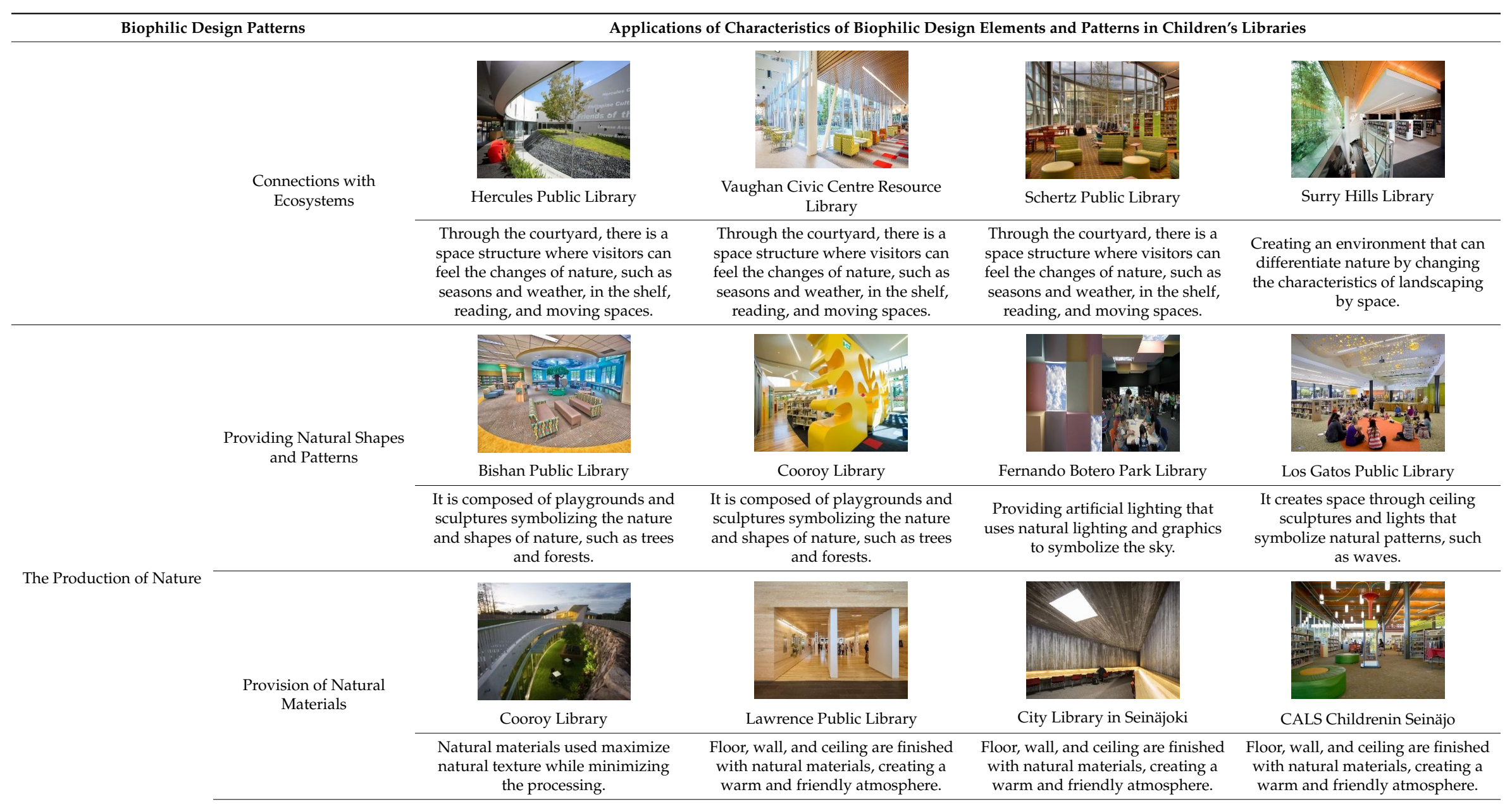


Table 4. Cont.

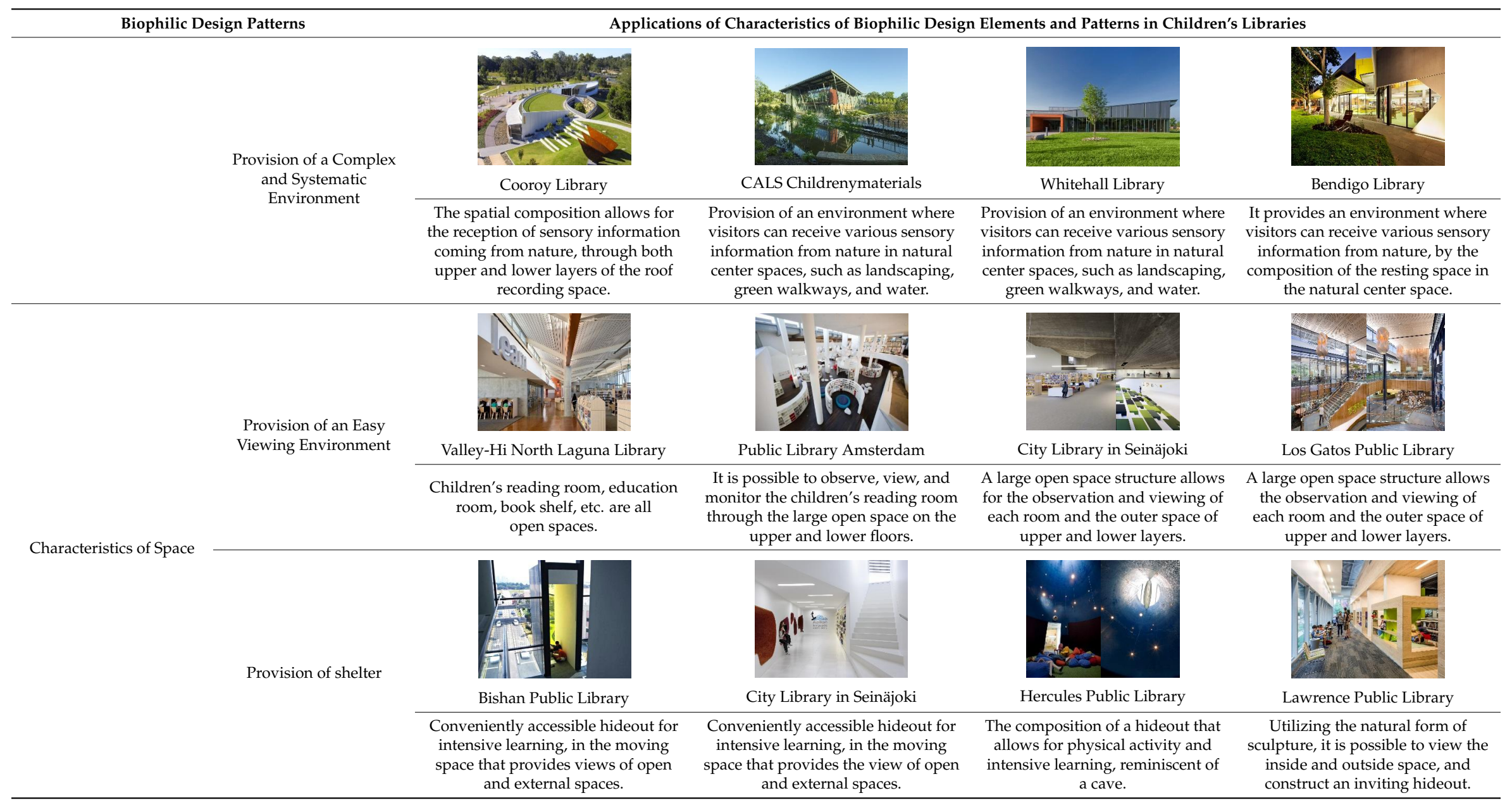




\section{Survey Results}

\subsection{General Information}

In this study, biophilic design pattern characteristics of a children's library were analyzed, and 33 questionnaires of nine patterns were set up. This study created a survey tool, including photographs of cases shown to help the respondents understand the questionnaire. Table 5 shows the generalities of the survey subjects.

We visited the children's reading room of the public library to evaluate the importance of biophilic design patterns for children's caregivers. A total of 261 respondents were surveyed, of which $82.4 \%$ were female; $50.6 \%$ percent were aged between 30 and 40 years; and $58.2 \%$ of children visited the library twice a month.

Table 5. Overview of Survey Subjects.

\begin{tabular}{cccc}
\hline Division & Item & f & \% \\
\hline \multirow{3}{*}{ Gender } & Male & 46 & 17.6 \\
& Female & 215 & 82.4 \\
& Total & 261 & 100 \\
\hline \multirow{2}{*}{ Age } & 20 to 30 years old & 116 & 44.4 \\
& 30 to 40 years old & 132 & 50.6 \\
& More than 40 years old & 13 & 5.0 \\
& Total & 261 & 100 \\
\hline \multirow{3}{*}{ Children's Library Monthly Visits } & $1-2$ times & 152 & 58.2 \\
& 3-4 times & 74 & 28.4 \\
& More than 5 times & 35 & 13.4 \\
& Total & 261 & 100 \\
\hline
\end{tabular}

\subsection{Importance of Biophilic Design Patterns in Children's Libraries}

The overall importance average that caregivers gave to biophilic design patterns was 3.81. The top five important averages of biophilic design patterns were as follows: 'Provision of an environment for easy viewing' (4.25); 'Visual connection with nature' (3.88); 'Connecting with ecosystems' (3.86); 'Dynamic light in the environment' (3.80); and the 'Provision of natural materials' (3.79).

The top priority items were 'Space design that facilitates visual connection with nature in a learning space with a long stay time' (4.42); 'Children's reading room, education room, and study room are all open and observable spaces' (4.33); 'Environment where visitors can receive various forms of sensory information from nature, by the composition of a resting space in the natural center' (4.26); 'A space where children's reading room can be observed through a large open space in the upper and lower layers' (4.25); 'Visual connection with nature by organizing the upper and lower floors of the library study/reading space as a large-scale open space' (4.19); 'Space structure that allows for the observation of outer space and each floor through a large open space' (4.17), and 'Natural lighting environment was reflected in the dynamic lighting in the environment, including an intensive learning space' (4.15). Table 6 shows the results of evaluating the importance that child caregivers gave to the biophilic design of children's libraries.

The overall average, as the result of evaluating the responses of children's caregivers as to the importance of the biophilic design patterns of children's libraries, was 3.81. 
Table 6. The Importance of Biophilic Design Elements and Patterns in Children's Libraries.

\begin{tabular}{|c|c|c|c|}
\hline Biophilic Design Patterns & $\begin{array}{l}\text { Applications of Characteristics of Biophilic Design Elements and Patterns in } \\
\text { Children's Libraries }\end{array}$ & & \\
\hline \multirow{6}{*}{ Visual Connection with Nature } & $\begin{array}{l}\text { Visual connection with nature through the organization of upper and lower layers, such as library } \\
\text { bookshelves/reading spaces as large-scale open spaces. }\end{array}$ & 4.19 & \multirow{6}{*}{3.88} \\
\hline & Delivering a new image of nature through the partial blocking of external viewing. & 3.27 & \\
\hline & $\begin{array}{l}\text { Space design that can stably and comfortably allow for gazing at the nature outside, while } \\
\text { seated indoors. }\end{array}$ & 3.88 & \\
\hline & Space design that facilitates a visual connection with nature in a learning space with a long stay time. & 4.42 & \\
\hline & $\begin{array}{l}\text { Using the light transmitted through a shade of green to create a space where the nature outside } \\
\text { looks greener. }\end{array}$ & 3.72 & \\
\hline & $\begin{array}{l}\text { Space design that facilitates the visibility of the nature outside in the interior space through the } \\
\text { visual penetration of the overlapping spaces. }\end{array}$ & 3.81 & \\
\hline \multirow{4}{*}{ Non-Visual Connection with Nature } & $\begin{array}{l}\text { The play/learning space that children often touch is enclosed with natural materials, such as wood, } \\
\text { to provide tactile and olfactory stimulation. }\end{array}$ & 3.78 & \multirow{4}{*}{3.66} \\
\hline & $\begin{array}{l}\text { Natural materials, such as wood, are used on the space elements with various functions, such as key } \\
\text { height measurements, to provide tactile and olfactory stimulation. }\end{array}$ & 3.81 & \\
\hline & Sand playground in an outer space to provide tactile stimulation by natural elements. & 3.18 & \\
\hline & $\begin{array}{l}\text { Provision of natural tactile and olfactory stimulation through an outside recording space that has } \\
\text { functions such as gathering, play, and performance. }\end{array}$ & 3.87 & \\
\hline \multirow{7}{*}{ Provides a dynamic light environment } & $\begin{array}{l}\text { Natural lighting was reflected in the dynamic lighting of the environment, including the intensive } \\
\text { learning space. }\end{array}$ & 4.15 & \multirow{7}{*}{3.80} \\
\hline & $\begin{array}{l}\text { Exposing the sky from the ceiling, providing a natural ecosystem view and dynamic light in the } \\
\text { environment, in the shelf, viewing, and moving spaces. }\end{array}$ & 3.84 & \\
\hline & $\begin{array}{l}\text { Natural light of the light well provides a dynamic light in the environment for viewing, playing and } \\
\text { learning spaces with a long stay time. }\end{array}$ & 4.01 & \\
\hline & $\begin{array}{l}\text { Provision of a moving space around the skylight to provide the natural light to be transmitted and } \\
\text { form interesting patterns, such as shadows. }\end{array}$ & 3.48 & \\
\hline & $\begin{array}{l}\text { Provision of dynamic light in the environment that changes momentarily in the shelf, reading, and } \\
\text { moving spaces by the natural light passing through the window. }\end{array}$ & 3.95 & \\
\hline & $\begin{array}{l}\text { Provision of artificial lighting with specific functions, such as floor movement guidance, and a } \\
\text { dynamic emphasis on vertical movement space and sunken space. }\end{array}$ & 3.97 & \\
\hline & $\begin{array}{l}\text { Provision of dynamic light in the environment through a finishing material that provides various } \\
\text { materials and reflectance, such as transmission, reflection, and color. }\end{array}$ & 3.24 & \\
\hline \multirow{2}{*}{ Connections with Ecosystems } & $\begin{array}{l}\text { Through the courtyard, there is a space structure where visitors can feel the changes of nature, such } \\
\text { as seasons and weather, in shelf, reading, and moving spaces. }\end{array}$ & 4.06 & \multirow[b]{2}{*}{3.86} \\
\hline & $\begin{array}{l}\text { Creating an environment that can make a difference in nature by changing the characteristics of } \\
\text { landscaping by space. }\end{array}$ & 3.67 & \\
\hline
\end{tabular}


Table 6. Cont

\begin{tabular}{|c|c|c|c|}
\hline Biophilic Design Patterns & $\begin{array}{l}\text { Applications of Characteristics of Biophilic Design Elements and Patterns in } \\
\text { Children's Libraries }\end{array}$ & & \\
\hline \multirow{3}{*}{ Provision of Natural Shapes and Patterns } & $\begin{array}{l}\text { It is composed of playgrounds and sculptures symbolizing the nature and shapes of nature, such as } \\
\text { trees and forests. }\end{array}$ & 3.49 & \multirow{3}{*}{3.54} \\
\hline & Provision of artificial lighting that uses natural lighting and graphics to symbolize the sky. & 3.61 & \\
\hline & It creates space through ceiling sculptures and lights that symbolize natural patterns, such as waves. & 3.54 & \\
\hline \multirow[b]{2}{*}{ Provision of Natural Materials } & Natural materials used maximize natural texture while minimizing the processing. & 3.64 & \multirow[b]{2}{*}{$3.7 \mathrm{c}$} \\
\hline & $\begin{array}{l}\text { Floor, wall, and ceilings are finished with natural materials, creating a warm and } \\
\text { friendly atmosphere. }\end{array}$ & 3.94 & \\
\hline \multirow{3}{*}{$\begin{array}{l}\text { Provision of a Complex and Systematic } \\
\text { Environment }\end{array}$} & $\begin{array}{l}\text { The spatial composition allows for the reception of sensory information coming from nature through } \\
\text { both the upper and lower layers of the roof recording space. }\end{array}$ & 3.16 & \multirow{3}{*}{3.62} \\
\hline & $\begin{array}{l}\text { Provision of an environment where visitors can receive various forms of sensory information from } \\
\text { nature, in natural center spaces, such as landscaping, green walkways, and water. }\end{array}$ & 3.44 & \\
\hline & $\begin{array}{l}\text { It provides an environment where visitors can receive various forms of sensory information from } \\
\text { nature, by the composition of a resting space in the natural center space. }\end{array}$ & 4.26 & \\
\hline \multirow{3}{*}{ Provision of Easy Viewing Environments } & Children's reading room, education room, book shelf, etc. are all open spaces. & 4.33 & \multirow{3}{*}{4.25} \\
\hline & $\begin{array}{l}\text { It is possible to observe, view, and monitor the children's reading room through the large open space } \\
\text { on the upper and lower floors. }\end{array}$ & 4.25 & \\
\hline & $\begin{array}{l}\text { A space structure that allows for the observation and viewing of each room and outer space of upper } \\
\text { and lower layers through a large open space. }\end{array}$ & 4.17 & \\
\hline \multirow{4}{*}{ Provision of Shelter } & $\begin{array}{l}\text { Conveniently accessible hideout for intensive learning in the moving space that provides views of } \\
\text { open and external spaces. }\end{array}$ & 4.01 & \multirow{3}{*}{3.8} \\
\hline & $\begin{array}{l}\text { The composition of a hideout that allows for physical activity and intensive learning, reminiscent of } \\
\text { a cave. }\end{array}$ & 3.85 & \\
\hline & $\begin{array}{l}\text { Utilizing the natural form of sculpture, it is possible to view the inside and outside space, and } \\
\text { construct an inviting hideout. }\end{array}$ & 3.68 & \\
\hline & Overall Average & & \\
\hline
\end{tabular}


The top priority items were 'Space design that facilitates visual connection with nature in learning spaces with long stay times' (4.42); 'Children's reading room, education room, study room are all open and observable spaces' (4.33); 'Environment where visitors can receive forms of various sensory information from nature, by the composition of a resting space in the natural center space' (4.26); 'A space where the children's reading room can be observed through a large open space in the upper and lower layers' (4.25); 'Visual connection with nature by organizing the upper and lower floors of the library study/reading space as a large-scale open space' (4.19); 'Space structure that allows for the observation of outer space and each floor through a large open space' (4.17); and 'Natural lighting environment was reflected in the dynamic lighting environment, including the intensive learning space and lobby'(4.15).

The characteristics of the biophilic design of children's libraries, which have a high level of importance in general, intend to create a pleasant environment through a visual and non-visual connection with nature and natural light in learning spaces, such as the children's reading room and education room. The formation of an environment where stereoscopic observation, viewing, or monitoring is easy in the same floor or another floor is also important. Therefore, these results explain the importance of direct experiences of nature [13] such as light, plants, and water through the openness of the library in architectural applications of biophilic design.

\subsection{Factors and Characteristics of Children's Libraries Based on Biophilic Design}

In this study, the factor analysis was conducted based on the importance evaluation results in order to identify the characteristics of the children's libraries based on biophilic design (Table 7).

The aim of the factor analysis is to suggest a space design plan based on the biophilic design of children's libraries, according to factors that the children's caregivers consider important. As a result of the factor analysis, factors were classified into five categories, and the explanatory power (cumulative percent of rotational sums) of all factors was $71.957 \%$. The first factor was 'Open space design that allows for easy observation, viewing, and monitoring'; the second factor was 'Design spaces for experiencing nature'; the third factor was 'An interesting space design, using natural elements'; the fourth factor was 'Interesting space design using natural elements'; and the fifth factor was 'Spatial design capable of providing for various sensory experiences'.

The most important of all was the second factor, 'Design a Learning Space that Can Experience Nature' (4.09); followed by the first factor, 'Open Space Design that Allows for Easy Observation, Viewing, and Monitoring' (4.06); the third factor, 'Space Design to Support Multiple Functions' (3.92); the fourth factor, 'Interesting Space Design using Natural Elements' (3.56); and the fifth factor, 'Spatial Design Capable of Providing for Various Sensory Information Experiences' (3.26).

The results of the factor analysis demonstrate that we should construct various learning spaces through the use of various factors of nature such as natural light, from an ecosystem point of view. In addition, taking into consideration the characteristics of the space mainly used by children, it is important to establish an open environment that facilitates observation and surveillance by utilizing dynamic natural light or artificial lighting, thereby securing safety and attracting interest. Especially, the external space that is directly in contact with nature is formed as a green space with various functions such as gathering, play, and performance, and it is important to create a space with multiple functions received from nature's attributes. This is a result of emphasizing the importance of the space design, which strengthens the collection and experience of various forms of information through learning and play based on the natural elements of the children's library as a whole. 
Table 7. Factor Analysis of Biophilic Design Patterns in Children's Libraries.

\begin{tabular}{|c|c|c|c|c|}
\hline Factor & Characteristics of Environmentally-Friendly Design Patterns of Children's Libraries & Component Quantity & & \\
\hline \multirow{9}{*}{$\begin{array}{l}\text { Open Space Design that is Easy } \\
\text { to Observe, View, and Monitor }\end{array}$} & Children's reading room, education room, book shelf, etc. are all open spaces. & 0.899 & 4.33 & \multirow{9}{*}{4.06} \\
\hline & $\begin{array}{l}\text { Large open spaces in the upper and lower floors provide space for observing, viewing, and } \\
\text { monitoring children's reading rooms. }\end{array}$ & 0.864 & 4.25 & \\
\hline & $\begin{array}{l}\text { The upper and lower floors of the library shelf/reading space are constructed as a large-scale open } \\
\text { space. }\end{array}$ & 0.792 & 4.19 & \\
\hline & $\begin{array}{l}\text { Observation and viewing of each room and outer space of upper and lower layers through a large } \\
\text { open space. }\end{array}$ & 0.754 & 4.17 & \\
\hline & $\begin{array}{l}\text { Provision of artificial lighting with specific functions, such as floor movement guidance and dynamic } \\
\text { emphasis on vertical movement space and sunken space. }\end{array}$ & 0.701 & 3.97 & \\
\hline & $\begin{array}{l}\text { Space where visitors can feel the changes of nature, such as seasons and weather, in the shelf, } \\
\text { reading, and moving spaces through the courtyard. }\end{array}$ & 0.658 & 4.06 & \\
\hline & $\begin{array}{l}\text { Provision of a dynamic light environment that changes momentarily in the shelf, reading, and } \\
\text { moving spaces by the natural light passing through the window. }\end{array}$ & 0.612 & 3.95 & \\
\hline & $\begin{array}{l}\text { Exposing the sky from the ceiling, providing a natural ecosystem view and dynamic light in the } \\
\text { environment, in the shelf, reading, and moving spaces. }\end{array}$ & 0.569 & 3.84 & \\
\hline & $\begin{array}{l}\text { Space design that facilitates viewing the nature outside while in the interior space through the visual } \\
\text { penetration of the overlapping spaces. }\end{array}$ & 0.512 & 3.81 & \\
\hline \multirow{6}{*}{$\begin{array}{l}\text { Design a Learning Space that } \\
\text { Can Experience Nature }\end{array}$} & Space design that facilitates a visual connection with nature in learning spaces with long stay times. & 0.825 & 4.42 & \multirow{6}{*}{4.09} \\
\hline & $\begin{array}{l}\text { Provision of dynamic lighting in the environment, such as intensive study spaces and lobbies, by } \\
\text { allowing for natural light to pass through the skylight. }\end{array}$ & 0.753 & 4.15 & \\
\hline & $\begin{array}{l}\text { Easy-access, sheltered area for intensive learning in open spaces to enable an open view of the inside } \\
\text { and outside spaces. }\end{array}$ & 0.677 & 4.11 & \\
\hline & $\begin{array}{l}\text { Natural light from the light well provides a dynamic light in the environment for viewing, playing } \\
\text { and learning spaces with long stay times. }\end{array}$ & 0.602 & 4.01 & \\
\hline & $\begin{array}{l}\text { Utilizing the natural form of sculpture, it is possible to view the inside and outside space, and } \\
\text { construct an interesting hideout. }\end{array}$ & 0.557 & 3.97 & \\
\hline & $\begin{array}{l}\text { Space design that allows visitors to view the nature outside in a stable and comfortable manner, } \\
\text { while seated indoors. }\end{array}$ & 0.501 & 3.88 & \\
\hline
\end{tabular}


Table 7. Cont.

\begin{tabular}{|c|c|c|c|c|}
\hline Factor & Characteristics of Environmentally-Friendly Design Patterns of Children's Libraries & Component Quantity & & \\
\hline \multirow{5}{*}{$\begin{array}{l}\text { Space Design to Support } \\
\text { Multiple Functions }\end{array}$} & $\begin{array}{l}\text { It provides an environment where visitors can feel various forms of sensory information from nature } \\
\text { by organizing reading and resting spaces in the natural center space. }\end{array}$ & 0.799 & 4.26 & \multirow{5}{*}{3.92} \\
\hline & Constructing a hideout that allows for physical activity and intensive learning, reminiscent of a cave. & 0.725 & 3.99 & \\
\hline & $\begin{array}{l}\text { Natural materials, such as wood, are used on space elements with various functions, such as key } \\
\text { height measurements, and provide tactile and olfactory stimulation. }\end{array}$ & 0.654 & 3.81 & \\
\hline & $\begin{array}{l}\text { Provision of natural tactile and olfactory stimulation through the outside recording space with } \\
\text { functions such as gathering, play, and performance. }\end{array}$ & 0.597 & 3.87 & \\
\hline & $\begin{array}{l}\text { Differentiation of characteristics of landscaping by space, creating an environment where visitors can } \\
\text { feel various natural changes. }\end{array}$ & 0.481 & 3.67 & \\
\hline \multirow{5}{*}{$\begin{array}{l}\text { An Interesting Space Design, } \\
\text { Using Natural Elements }\end{array}$} & $\begin{array}{l}\text { Using the light transmitted through a shade of green, creating a space that looks greener than the } \\
\text { nature outside. }\end{array}$ & 0.725 & 3.72 & \multirow{5}{*}{3.5} \\
\hline & Provision of artificial lighting that uses natural lighting and graphics to symbolize the sky. & 0.674 & 3.61 & \\
\hline & It creates space through ceiling artworks and lighting that symbolize natural patterns, such as waves. & 0.598 & 3.54 & \\
\hline & $\begin{array}{l}\text { Organization of playgrounds through sculptures symbolizing the nature and shapes of nature, such } \\
\text { as trees and forests. }\end{array}$ & 0.513 & 3.49 & \\
\hline & $\begin{array}{l}\text { Provision of a moving space around the skylight to allow for the natural light to be transmitted } \\
\text { through, and form interesting shadow formations. }\end{array}$ & 0.461 & 3.48 & \\
\hline \multirow{5}{*}{$\begin{array}{l}\text { Space Design that Allows for } \\
\text { the Experience of Various Forms } \\
\text { of Sensory Information }\end{array}$} & $\begin{array}{l}\text { Provision of an environment where visitors can feel various forms of sensory information of nature } \\
\text { in the natural center space, such as landscaping, green walkways, and water. }\end{array}$ & 0.684 & 3.44 & \multirow{5}{*}{3.2} \\
\hline & Delivering a new image of nature through partial blocking of the external view. & 0.618 & 3.27 & \\
\hline & $\begin{array}{l}\text { Provision of dynamic light in the environment through a finishing material that provides reflectance, } \\
\text { such as transmission, reflection, and color. }\end{array}$ & 0.557 & 3.24 & \\
\hline & $\begin{array}{l}\text { Provision of tactile stimulation by natural elements, by constructing a sand playground in the } \\
\text { outer space. }\end{array}$ & 0.512 & 3.18 & \\
\hline & $\begin{array}{l}\text { Space in the upper and lower layers where visitors can feel various forms of sensory information of } \\
\text { nature through the roofing green space. }\end{array}$ & 0.413 & 3.16 & \\
\hline
\end{tabular}

* Factor Extraction Method: Principal component analysis, rotation method: Verimax with Kaiser normalization, factor rotation convergence in 26 iterations, shaded part is more than 4.0. 


\subsection{Limitation and Contribution to Sustainability}

In built environment, 'sustainability' has the task of utilizing regional natural resources for humans from an anthropological point of view. The application of regional natural resources could offer psychological emotional stability, because every human being has a strong preference for nature. The biophilic design patterns covered in this study suggest the architectural planning elements that are related to the direct and indirect application of positive natural elements in order to satisfy human physical and mental needs in the interior and exterior spaces of the buildings. Therefore, the contribution of this study is its approach, which suggests a potential route for satisfying these needs and creating a sustainable environment through systematically analyzing the characteristics and importance of biophilic design patterns in a children's library.

However, in the research results of this study, 'sustainability' is limited to specific buildinga children's library-and does not provide a macro perspective, such as that of urban design.

\section{Conclusions}

This study aimed to suggest a space design method for children's libraries based on biophilic design patterns in order to investigate the characteristics of biophilic design patterns of children's libraries located overseas; and to conduct a survey on the importance that children's caregivers give to such design patterns. Based on the results of this study, the following conclusions are presented.

First, children's libraries need to design various learning spaces that provide for the experience of nature. It is necessary to create a reading and learning environment that can reduce fatigue. To achieve this, it is necessary to create an environment in which a natural ecosystem can be viewed and observed in a relaxed state while seated indoors, as well as provide a simple view from a learning space. It is also necessary to make use of natural elements that can induce interest in various learning spaces, such as the active utilization of dynamic natural light passing through light wells of various colors, and the utilization of natural forms of sculpture.

Second, children's libraries need hideout space designs that are accessible and have a view. It is essential for children's intensive learning and interaction with small groups that the access is easy and that the surrounding environment can be viewed. In addition, shelter plays an important role in enhancing children's emotional development and cognitive abilities by providing psychological stability, such as tranquility and safety in an unfamiliar environment. Therefore, the shelter space design should be placed near the horizontal or vertical movement path to increase the accessibility; utilize natural molding such as a cave, mountain, or wave form; or actively utilize natural materials to induce the interest of children. The experience of various forms of sensory information should be provided for, and children should be able to view the external environment.

Third, children's libraries need open space designs to secure visibility in various spaces. Such space designs should provide for the observation and viewing of complex natural ecosystems, such as vegetation and water systems; the observation of seasonal changes; and the observation and monitoring of children's activities in the library in terms of security. For this purpose, it is necessary to provide an environment that allows the visitor to visually experience the inside and outside through a large-scale open space design between horizontal and vertical spaces. Also, in a moving space or a space similar to that of a passageway that overlaps between spaces, such as a passageway inside a shelf, etc., it is possible to open a skylight or a side window to create dynamic light in the environment that allows for the observation of changes in the sky or natural light over time.

Fourth, children's libraries need multi-functional space designs that enable children of various ages to interact with each other. The children's library is a facility where learning, exchange, and play should be possible through the acquisition of various forms of information. Therefore, it is necessary to consider a spatial design that provides for various experiences, such as reading, rest, gathering, play, and performance. These can be applied in natural center spaces, or by applying various natural elements to the inner and outer spaces. 
Fifth, children's libraries need space designs that can induce interest and experiences through various forms of sensory information created by the utilization of natural elements. Children develop physical and cognitive abilities through visual and non-visual experiences, such as tactile, auditory, and olfactory sensations, during their development and growth. Therefore, it is necessary for children's libraries to create a space where visitors can experience the materials and forms of nature as much as possible, with the application of patterns such as green walkways, a sand playground, and natural materials with minimal processing. In addition, space designs should provide a dynamic light environment through the use of various colors of glass or awnings to create an environment that is capable of providing the experience of feeling the changes in the external environment, or through reflectance, such as transmission, reflection, and color. This research suggests a methodological route to preferentially apply biophilic design patterns in the space through linking the indoor space of the children's library with the biophilic design patterns and a starting point for discussing the application of biophilic design patterns in other spaces.

In further studies, it is necessary to conduct a detailed study on the satisfaction levels of children, and the importance that children give to biophilic design patterns that have been applied in children's libraries, which consider their growth and development.

Acknowledgments: This work was supported by the National Research Foundation of Korea (NRF) grant funded by the Korea Government (MEST) (NRF-2016S1A5A8017890); This work was supported by the National Research Foundation of Korea (NRF) grant funded by the Korea Government (MEST) (NRF-2015R1C1A1A02037539).

Author Contributions: Hyo Chang Lee and Sung Jun Park conceived and designed the research and wrote the paper; Hyo Chang Lee analyzed the data; Sung Jun Park critically reviewed the article.

Conflicts of Interest: The authors declare no conflict of interest.

\section{References}

1. Shin, D.J.; Kim, J.Y.; Lee, S.H. A Study on the Color Status of Interior Space in the Korean Professional Children Libraries. J. Korean Inst. Cult. Archit. 2013, 36, 35.

2. Yeun, M.K. Research on Program Development of Infant Art on the basis of Multi-Intelligence Theory. J. Korea Child Art Assoc. 2013, 12, 70.

3. Baek, J.E.; Yoon, J.E. Study on Nature Experiential Characteristics of Space Experience in Children's National Folk Museum of Korea. J. Korea Inst. Spat. Des. 2016, 11, 92.

4. Ha, M.K.; Lee, H.S. A Study on Space Design based on Biophilic Design of Refuge for Child Development. J. Korean Inst. Cult. Archit. 2017, 60, 66.

5. Bronfenbrenner, U. The Ecology of Human Development; Harvard University Press: Cambridge, MA, USA, 1979.

6. Choi, K.S. Child Developmental Psychology; Gyomoon Publishers: Seoul, Korea, 2006; p. 86.

7. Kim, H.J. Consciousness and Awareness of Children's Library Librarians; Library Science Society of Chung-Ang University: Seoul, Korea, 1973; pp. 220-222.

8. Kim, KI. Library and children reading. Library 1991, 245, 57.

9. Lee, Y.J.; Whang, H. A Study on the physical characteristics of children's library supporting children's development. J. Korean Inst. Cult. Archit. 2011, 36, 35.

10. Han, H.R.; Park, Y. A Basic Study on the Demand of the Parents of Students in Eco-Environmental Space at Child Care Center. J. Korean Inst. Inter. Des. 2007, 16, 49.

11. Kaplan, R.; Kaplan, S. The Experience of Nature: A Psychological Perspective; CUP Archive: New York, NY, USA, 1989.

12. Ulrich, R.S.; Simons, R.F.; Losito, B.D.; Fiorito, E.; Miles, M.A.; Zelson, M. Stress recovery during exposure to natural and urban environments. J. Environ. Psychol. 1991, 11, 201-230. [CrossRef]

13. Gillis, K.; Gatersleben, B. A review of psychological literature on the health and wellbeing benefits of biophilic design. Buildings 2015, 5, 948-963. [CrossRef]

14. Browning, W.D.; Ryan, C.O.; Clancy, J.O. Patterns of Biophilic Design; Terrapin Bright Green LLC: New York, NY, USA, 2014; Volume 14, p. 12. 